\title{
Tissue-specific correction of lipogenic enzyme gene expression in diabetic rats given vanadate
}

\author{
S.M. Brichard ${ }^{1}$, L.N. Ongemba ${ }^{1}$, J. Girard ${ }^{2}$, J.-C. Henquin ${ }^{1}$ \\ ${ }^{1}$ Unité d'Endocrinologie et Métabolisme, University of Louvain, Faculty of Medicine, Brussels, Belgium; ${ }^{2} \mathrm{CNRS}$, Meudon, France
}

\begin{abstract}
Summary Vanadium is a potent insulinomimetic agent. In vivo, its blood glucose lowering action in insulin-deficient diabetic rats is associated with corrected expression of genes involved in hepatic glucose metabolism. In this study, we investigated whether vanadate treatment also reverses the impaired expression of genes coding for key enzymes of lipogenesis in diabetic liver and white adipose tissue. Oral administration of vanadate to streptozotocin-rats caused a $55 \%$ fall in plasma glucose levels after feeding without modifying low insulinaemia. It also partially corrected the low thyroid hormone concentrations. In untreated diabetic animals, hepatic mRNA levels of acetyl-CoA carboxylase and fatty acid synthase were reduced by more than 80 and $90 \%$, respectively, in close correlation with changes in enzyme activities. Three weeks of vanadate treatment totally restored acetyl-CoA carboxylase mRNA and
\end{abstract}

partially restored fatty acid synthase mRNA ( $71 \%$ of control levels). The activities of both lipogenic enzymes were increased 3.5 to 4 -fold, to reach 45 to $65 \%$ of control values. By contrast, in white adipose tissue, vanadate modified neither expression nor activity of both lipogenic enzymes, which remained blunted ( $<10 \%$ of control levels). In conclusion, vanadate treatment partially restores the activities of two key lipogenic enzymes in liver, but not in white adipose tissue, of diabetic rats. This correction results from a reversal of impaired pre-translational regulatory mechanisms possibly mediated by an improvement of thyroid function and a selective restoration of liver glycolytic flux. [Diabetologia (1994) 37:1065-1072]

Key words Vanadium, lipogenic enzymes, gene expression, streptozotocin-diabetic rats.
In diabetes, abnormalities of lipogenesis and lipolysis lead to a gradual elevation of plasma non-esterified fatty acids, which worsens the insulin resistance in muscles and augments glucose production by the liver. These disorders of fat metabolism, therefore,

Received: 16 March 1994

and in revised form: 20 May 1994

Corresponding author: Dr. S. M. Brichard, Unité d'Endocrinologie et Métabolisme, UCL 5530, 55, Avenue Hippocrate, B1200 Brussels, Belgium

Abbreviations: ACC, Acetyl-CoA carboxylase; FAS, fatty acid synthase; PEPCK, phosphoenolpyruvate carboxykinase; $\mathrm{C}$, non-diabetic control rats; $\mathrm{D}$, untreated diabetic rats; $\mathrm{V}$, vanadate-treated diabetic rats; SSC, sodium saline citrate; SDS, sodium dodecyl sulphate; OD, optical density; kb, kilobase. contribute to promote and maintain the alterations of glucose homeostasis [1].

The trace element vanadium is a potent insulinomimetic agent in various cell types. Its insulin-like properties have usually been ascribed to enhanced phosphorylation of the insulin receptor, although mechanisms distal to the receptor may also be involved $[2,3]$. Oral administration of vanadium salts to insulin-deficient rats markedly lowers blood glucose concentrations without modifying low levels of insulinaemia [4-8]. Considerable attention has thus been recently focused on the in vivo effects of vanadate on carbohydrate metabolism $[2,3]$. However, fewer and less extensive studies have examined its influence on lipid metabolism in vivo [9-11]. It is now well established that vanadate treatment is able to restore the abnormal expression of genes involved in glucose 
metabolism in liver of diabetic rats $[12,13]$. Its effect on lipogenic enzyme expression has never been studied.

In the present study, we investigated whether vanadate administration to streptozotocin-diabetic rats could reverse the impaired expression of genes involved in key steps of lipogenesis in the two major sites involved in this metabolic pathway: liver and white adipose tissue. To this end, we measured mRNA levels and activities of acetyl-CoA carboxylase (ACC) and fatty acid synthase (FAS) in vanadate-treated rats.

\section{Materials and methods}

Animals and experimental design. Male Wistar/CPB rats (7 weeks old; $221 \pm 2 \mathrm{~g}$ ) were purchased from IFFA Credo (Brussels, Belgium). All rats received standard laboratory chow ad libitum (A04, UAR, Villemoisson-sur-Orge, France; $\%$ of wet weight: $59 \%$ carbohydrate, $3 \%$ fat, $17 \%$ protein, $21 \%$ water-minerals-cellulose). They were housed in individual cages at a constant temperature $\left(22^{\circ} \mathrm{C}\right)$ with a fixed 12 h-light-dark cycle (lights on 07.00-19.00 hours).

The animals were divided into three experimental groups: non-diabetic control rats $(C ; n=6)$; untreated diabetic rats (D; $n=6)$; diabetic rats treated with vanadate ( $\mathrm{V} ; n=5)$. Nonketotic diabetes was induced by an i. v. injection of streptozotocin ( $42.5 \mathrm{mg} / \mathrm{kg}$ body weight) into a tail vein. Streptozotocin (Upjohn Co, Kalamazoo, Mich., USA) was dissolved in cold $0.1 \mathrm{~mol} / 1$ citrate buffer ( $\mathrm{pH} 4.5$ ) immediately before use. Control animals received only the buffer. Five days after buffer injection, the body weight and plasma glucose levels of control rats averaged $250 \pm 2 \mathrm{~g}$ and $6.8 \pm 0.1 \mathrm{mmol} / \mathrm{l}$, respectively. Five days after streptozotocin injection, the diabetic rats were assigned to untreated or treated groups. The two groups of diabetic rats were matched for body weight (D: $222 \pm 1 \mathrm{~g}, \mathrm{~V}$ : $227 \pm 3 \mathrm{~g}, p>0.05)$ and plasma glucose levels after feeding (D: $22 \pm 1 \mathrm{mmol} / \mathrm{l}, \mathrm{V}: 22 \pm 1 \mathrm{mmol} / 1, p>0.05)$. The treated group received increasing amounts of sodium metavanadate ( $\mathrm{NaVO}_{3}$, Merck, Darmstadt, Germany) in drinking solutions (up to $0.35 \mathrm{mg} / \mathrm{ml}$ ), as previously described [14]. This concentration was reached after 15 days of treatment and was maintained until the end of the study. The progressive increase permitted us to partially overcome the aversion of the rats for vanadate.

On several occasions, tail vein blood was collected from fed animals for determination of plasma glucose levels. Plasma insulin levels were also measured in the final samples.

After 20 days of treatment, the rats were killed between 02.00 and 04.00 hours (i.e., in the absorptive state). Liver and pairs of epididymal fat pads were immediately removed, frozen in liquid nitrogen and stored at $-70^{\circ} \mathrm{C}$ for subsequent RNA extraction and enzyme measurement.

$R N A$ extraction and Northern blot analysis. Total RNA was isolated with an acid guanidinium-thiocyanate-phenol-chloroform mixture [15], after liver glycogen removal [16]. The concentration of RNA was determined by absorbance at $260 \mathrm{~nm}$. All samples had a $260 / 280$ absorbance ratio of about 1.8 . For Northern blot analysis, RNA ( $10 \mu \mathrm{g}$ for white adipose tissue, $20 \mathrm{\mu g}$ for liver) was denatured in a solution containing $2.2 \mathrm{mmol} / \mathrm{l}$ formaldehyde and $50 \%$ formamide (volume/volume) by heating at $95^{\circ} \mathrm{C}$ for $2 \mathrm{~min}$. RNA was then size-fractio- nated by $1 \%$ agarose gel electrophoresis, transferred to a $\mathrm{Hy}$ bond-N membrane (Amersham Int., Amersham, Bucks, UK) and cross-linked by ultraviolet irradiation. The integrity and relative amounts of RNA were assessed by methylene blue staining of the blot.

The cDNA probes were kindly supplied by Drs. K. H. Kim for ACC [17], A.G. Goodridge for FAS [18], R.W. Hanson for phosphoenolpyruvate carboxykinase (PEPCK) [19]. Probes were labelled with ${ }^{32} \mathrm{P}$ using the Multiprime labelling system kit (Amersham). Hybridizations with ACC and FAS probes were carried out in a medium containing $45 \%$ deionized formamide, $0.1 \mathrm{~mol} / 1 \mathrm{NaHPO} 4(\mathrm{pH} 6.5$ ), $4 \times$ sodium saline citrate (SSC), $1 \times$ Denhardt's solution (Denhardt $1 \times: 0.2$ $\mathrm{g} / 1$ polyvinylpyrrolidone, $0.2 \mathrm{~g} / \mathrm{l}$ bovine serum albumin, $0.2 \mathrm{~g} / \mathrm{l}$ ficoll 400 ), $10 \%$ dextran sulphate, $0.1 \%$ sodium pyrophosphate, $0.1 \%$ SDS and denatured herring sperm DNA $(0.15$ $\mathrm{mg} / \mathrm{ml}$ ) at $42^{\circ} \mathrm{C}$ overnight. Hybridizations with PEPCK probe were performed in $42 \%$ formamide, $40 \mathrm{mmol} / 1-\mathrm{Tris} / \mathrm{HCl}(\mathrm{pH}$ 7.5), $8 \times$ Denhardt's solution, $7.5 \%$ dextran sulphate, $0.1 \%$ sodium pyrophosphate, $1 \%$ SDS and denatured herring sperm DNA $(0.3 \mathrm{mg} / \mathrm{ml})$ at $42^{\circ} \mathrm{C}$ overnight. The membranes hybridized with FAS and ACC were washed three times for $20 \mathrm{~min}$ in $2 \times \mathrm{SSC} / 0.1 \% \mathrm{SDS}$ at $42^{\circ} \mathrm{C}$, twice for $30 \mathrm{~min}$ in $1 \times \mathrm{SSCl}$ $0.1 \% \mathrm{SDS}$ at $65^{\circ} \mathrm{C}$ and once for $10-30 \mathrm{~min}$ in $0.1 \times \mathrm{SSC} / 0.1 \%$ SDS at $65^{\circ} \mathrm{C}$. The membranes hybridized with PEPCK were first washed twice for $30 \mathrm{~min}$ in $2 \times \mathrm{SSC} 0.1 \% \mathrm{SDS}$ at $42^{\circ} \mathrm{C}$, then once or twice for $15-30 \mathrm{~min}$ in $0.1-0.5 \times \mathrm{SSC} / 0.1 \% \mathrm{SDS}$. The filters were thereafter exposed to Kodak X-OMAT AR films for $2-14 \mathrm{~h}$ at $-80^{\circ} \mathrm{C}$ with intensifying screens.

Intensity of the mRNA bands on the blots was quantified by scanning densitometry (Ultroscan XL; LKB, Bromma, Sweden). To normalize the amount of total RNA loaded on each lane, specific mRNA levels were expressed relative to those of $\beta$ actin mRNA, a house-keeping gene which did not vary between the three groups.

Measurements of enzyme activities. All enzyme activities were carried out at $37^{\circ} \mathrm{C}$. FAS activity was determined using the spectrophotometric assay of Linn [20]. Results were expressed as nmol NADPH oxidized per min per mg protein of tissue supernatant solutions (105000 g fractions). The maximal activity of ACC (EC 6.4.1.2) was measured according to Maeda et al. [21], after incubation in the presence of $10 \mathrm{mmol} / 1 \mathrm{ci}-$ trate, by the incorporation of $\mathrm{NaH}\left[{ }^{14} \mathrm{C}\right] \mathrm{O}_{3}$ into malonyl-CoA. The results were expressed as nmol malonyl-CoA formed per min per mg protein of Sephadex eluates from tissue supernatant solutions. PEPCK (EC 4.1.1.32) activity was determined in tissue cytosolic fractions using the $\mathrm{NaH}\left[{ }^{14} \mathrm{C}\right] \mathrm{O}_{3}$ fixation assay of Chang and Lane [22]. Results were expressed as nmol $\mathrm{NaH}\left[{ }^{14} \mathrm{C}\right] \mathrm{O}_{3}$ fixed per min per $\mathrm{mg}$ protein. One milliunit of enzyme is defined as that amount which catalyses the conversion of 1 nmol substrate per min under the conditions mentioned above.

Analytical procedures. Plasma glucose was measured by a glucose oxidase method (Glucose analyzer; Beckman, Fullerton, Calif., USA). Plasma insulin was determined by a double-antibody radioimmunoassay, using rat insulin as standard (Novo Research Institute, Bagsvaerd, Denmark). Plasma thyroid hormones were measured by radioimmunoassay using commercial kits (Abbott $\mathrm{T}_{3}$ Riabead; Abbott $\mathrm{GmbH}$ Diagnostika, Wiesbaden, Germany; Magic $\mathrm{T}_{4}$; Ciba Corning Diagnostics GmbH, Fernwald, Germany). Plasma NEFA was analysed using acetyl-coenzyme-A oxidase-based colorimetric kit (Wako NEFA-C; Wako Chemicals GmbH, Neuss, Germany). Proteins in tissue homogenates or in cytosolic fractions were determined by the method of Bradford (Bio-Rad, Munich, 
Table 1. Body weight, and plasma glucose, insulin, thyroid hormone and NEFA levels in fed rats of the three experimental groups

\begin{tabular}{lccc}
\hline & Control & Diabetic & Diabetic + vanadate \\
\hline $\begin{array}{l}\text { Body weight } \\
(\mathrm{g})\end{array}$ & $318 \pm 7$ & $230 \pm 5^{\mathrm{b}}$ & $229 \pm 4^{\mathrm{b}}$ \\
$\begin{array}{l}\text { Plasma glucose } \\
\text { (mmol/) }\end{array}$ & $5.5 \pm 0.1$ & $25.1 \pm 0.4^{\mathrm{b}}$ & $11.1 \pm 0.9^{\mathrm{b}, \mathrm{d}}$ \\
$\begin{array}{l}\text { Plasma insulin } \\
\text { (ng/ml) }\end{array}$ & $3.45 \pm 0.62$ & $0.82 \pm 0.09^{\mathrm{b}}$ & $1.19 \pm 0.15^{\mathrm{b}}$ \\
$\begin{array}{l}\text { Plasma T3 } \\
\text { (ng/dl) }\end{array}$ & $57 \pm 3$ & $30 \pm 2^{\mathrm{b}}$ & $40 \pm 2^{\mathrm{b}, \mathrm{c}}$ \\
$\begin{array}{l}\text { Plasma T4 } \\
(\mu \mathrm{g} / \mathrm{dl})\end{array}$ & $4.7 \pm 0.3$ & $1.5 \pm 0.2^{\mathrm{b}}$ & $3.4 \pm 0.5^{\mathrm{a}, \mathrm{d}}$ \\
$\begin{array}{l}\text { Plasma NEFA } \\
(\mu \mathrm{Eq} / 1)\end{array}$ & $145 \pm 3$ & $330 \pm 22^{\mathrm{b}}$ & $244 \pm 8^{\mathrm{b}, \mathrm{d}}$
\end{tabular}

${ }^{\mathrm{a}} p<0.05 ;{ }^{\mathrm{b}} p<0.01$ vs control rats ; ${ }^{\mathrm{c}} p<0.05 ;{ }^{\mathrm{d}} p<0.01$ vs untreated diabetic rats

Values are means \pm SEM for 5-6 rats in each group. Diabetes was induced by an i. $\%$ injection of streptozotocin 5 days before starting the treatment. One group of diabetic rats was untreated; the other group received $\mathrm{NaVO}_{3}$ in drinking solutions for 20 days. Control rats were injected with citrate buffer and did not receive vanadate. The values for body weight, and plasma thyroid hormone and NEFA levels are those measured at the end of the experiment. For plasma glucose and insulin measurements, two blood samples were taken during the last week of the study; the values obtained were averaged for each rat

Table 2. Characteristics of liver and white adipose tissue in the three groups of rats

\begin{tabular}{|c|c|c|c|}
\hline & Control & Diabetic & Diabetic + vanadate \\
\hline \multicolumn{4}{|l|}{ Liver } \\
\hline Weight $(g)$ & $11.7 \pm 0.4$ & $9.1 \pm 0.2^{b}$ & $10.5 \pm 0.3^{a, d}$ \\
\hline Protein $(\mathrm{mg} / \mathrm{g})$ & $151 \pm 4$ & $167 \pm 3^{b}$ & $146 \pm 2^{\mathrm{d}}$ \\
\hline RNA (mg/g) & $4.34 \pm 0.15$ & $4.12 \pm 0.10$ & $4.34 \pm 0.37$ \\
\hline \multicolumn{4}{|c|}{ White adipose tissue } \\
\hline DNA $(\mathrm{mg} / \mathrm{g})$ & $0.15 \pm 0.03$ & $0.70 \pm 0.22^{\mathrm{a}}$ & $0.35 \pm 0.08$ \\
\hline RNA (mg/g) & $0.11 \pm 0.01$ & $0.29 \pm 0.05^{\mathrm{b}}$ & $0.18 \pm 0.04^{c}$ \\
\hline
\end{tabular}

${ }^{\mathrm{a}} p<0.05,{ }^{\mathrm{b}} p<0.01$ vs control rats ; ${ }^{\mathrm{c}} p<0.05,{ }^{\mathrm{d}} p<0.01$ vs untreated diabetic rats

Germany) [23], using bovine serum albumin as standard. DNA was measured using a spectrofluorimetric method [24].

\section{Statistical analysis}

Results are given as the mean \pm SEM for the indicated number of rats. Comparisons between control, diabetic, and vanadatetreated diabetic rats were carried out by analysis of variance followed by the Newman-Keuls test for multiple comparisons [25]. Differences were considered statistically significant at $p<0.05$.

\section{Results}

Twenty-five days after streptozotocin injection, the body weight of diabetic rats was markedly reduced compared to that of controls. As previously reported $[7,13]$, this growth retardation was not improved by vanadate treatment (Table 1). Plasma glucose levels in fed diabetic rats were around $25 \mathrm{mmol} / 1$, and their
Values are means \pm SEM for 5-6 rats in each group. The animals were killed after 20 days of treatment. Weight refers to wet weight, white adipose tissue to epididymal fat pads

plasma insulin levels were decreased by $75 \%$. Vanadate administration to diabetic rats resulted in a $55 \%$ fall in glucose concentrations. This blood glucose lowering effect was not due to a rise in plasma insulin levels. The low concentrations of thyroid hormones in streptozotocin-diabetic rats were partly corrected by vanadate treatment, whereas the elevated levels of plasma NEFA were slightly decreased (Table 1).

The attenuation of hyperglycaemia in vanadatetreated rats was accompanied by a $75 \%$ reduction in fluid intake ( $49 \pm 4 \mathrm{ml} /$ day vs $211 \pm 9 \mathrm{ml} /$ day in $\mathrm{D}$ rats, $p<0.01$ ). During the last 5 days of the study, the average consumption of sodium metavanadate was $75 \pm 6 \mathrm{mg} \cdot \mathrm{kg}^{-1} \mathrm{day}^{-1}$, which corresponds to $21 \pm 2 \mathrm{mg}$ vanadium element $\cdot \mathrm{kg}^{-1} \mathrm{day}^{-1}$.

The characteristics of the two major tissues involved in lipogenesis are summarized in Table 2 . In liver, there were only slight differences in the parameters studied between the three test groups. By contrast, in white adipose tissue, diabetes induced a sharp reduction of fat pad weight, while increasing 


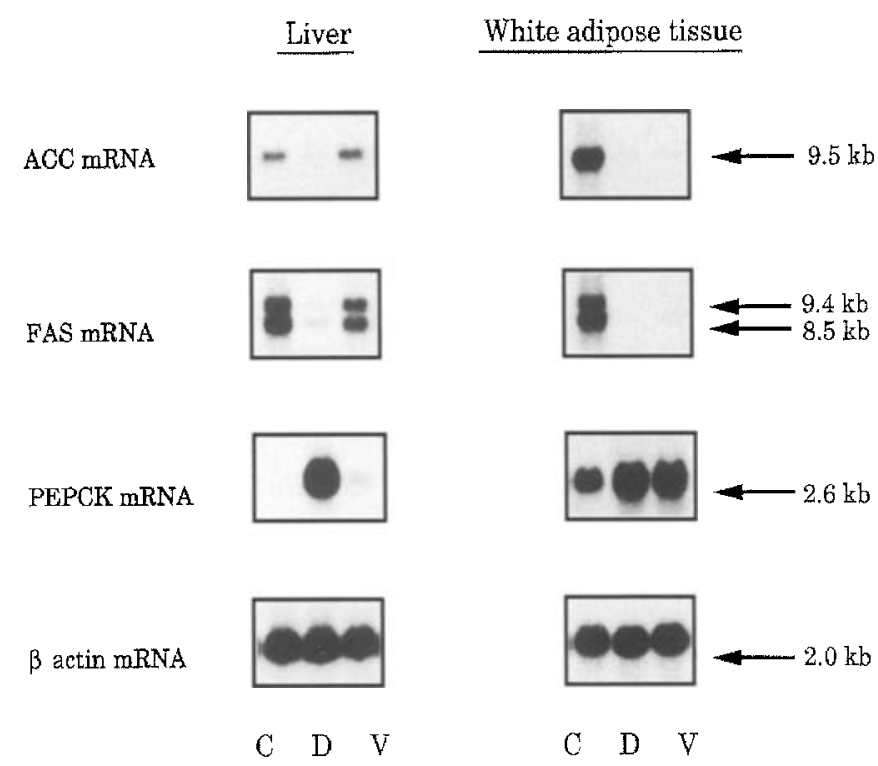

Fig. 1. Northern-blot analysis of acetyl-CoA carboxylase (ACC), fatty acid synthase (FAS), phosphoenolpyruvate carboxykinase (PEPCK) and $\beta$ actin mRNA in liver and white adipose tissue from control (C), untreated diabetic (D) and vanadate-treated diabetic (V) rats. All lanes were loaded with $20 \mu \mathrm{g}$ (liver) or $10 \mu \mathrm{g}$ (adipose tissue) of total RNA. The filters were then successively hybridized with the different radiolabelled cDNA probes. This figure is representative of 5-6 different rats in each group. $\mathrm{kb}$, kilobase

protein, DNA and total RNA concentrations. These concentrations reached intermediate levels in vanadate-treated rats.

To determine whether vanadate treatment of diabetic rats affects the altered expression of genes in- volved in key steps of lipogenesis, we measured mRNA levels of ACC and FAS in liver and white adipose tissue. The mRNA abundance was assessed by Northern blot analysis.

In liver, the mRNA transcripts of ACC ( 9.5 kilobases $(\mathrm{kb}))$ and FAS $(9.4$ and $8.5 \mathrm{~kb}$ ) were barely detectable in diabetic rats (Fig.1). Quantifications of autoradiographic signals showed that ACC and FAS mRNAs were decreased by more than 80 and $90 \%$, respectively, in diabetic rats compared to controls (Fig. 2). The activities of ACC and FAS were lowered accordingly (Table 3 ). Vanadate treatment totally corrected ACC mRNA and partially corrected FAS mRNA ( $71 \%$ of control levels) (Figs. 1 and 2). The activities of both lipogenic enzymes were restored to $45-65 \%$ of control values. Compared to untreated diabetic rats, these activities were increased 3.5- to 4-fold by vanadate treatment (Table 3 ). The gluconeogenic enzyme, PEPCK, served as an established control of vanadate action. In agreement with our previous results [13], PEPCK $m$ RNA and activity decreased to normal or near normal values after vanadate administration. PEPCK parameters were thus found to follow a reverse pattern to that of ACC and FAS in liver of the three groups of rats (Figs. 1 and 2, Table 3).

Diabetes also markedly reduced the expression and activity of both lipogenic enzymes in white adipose tissue ( $<10 \%$ of control levels). In contrast to the correction observed in the liver, vanadate treatment did not modify ACC and FAS mRNA and activity, which remained extremely low (Figs. 1 and 2, Table 3). Examination of PEPCK mRNA abundance on Northern blots (optical density (OD) / $\mu \mathrm{g}$

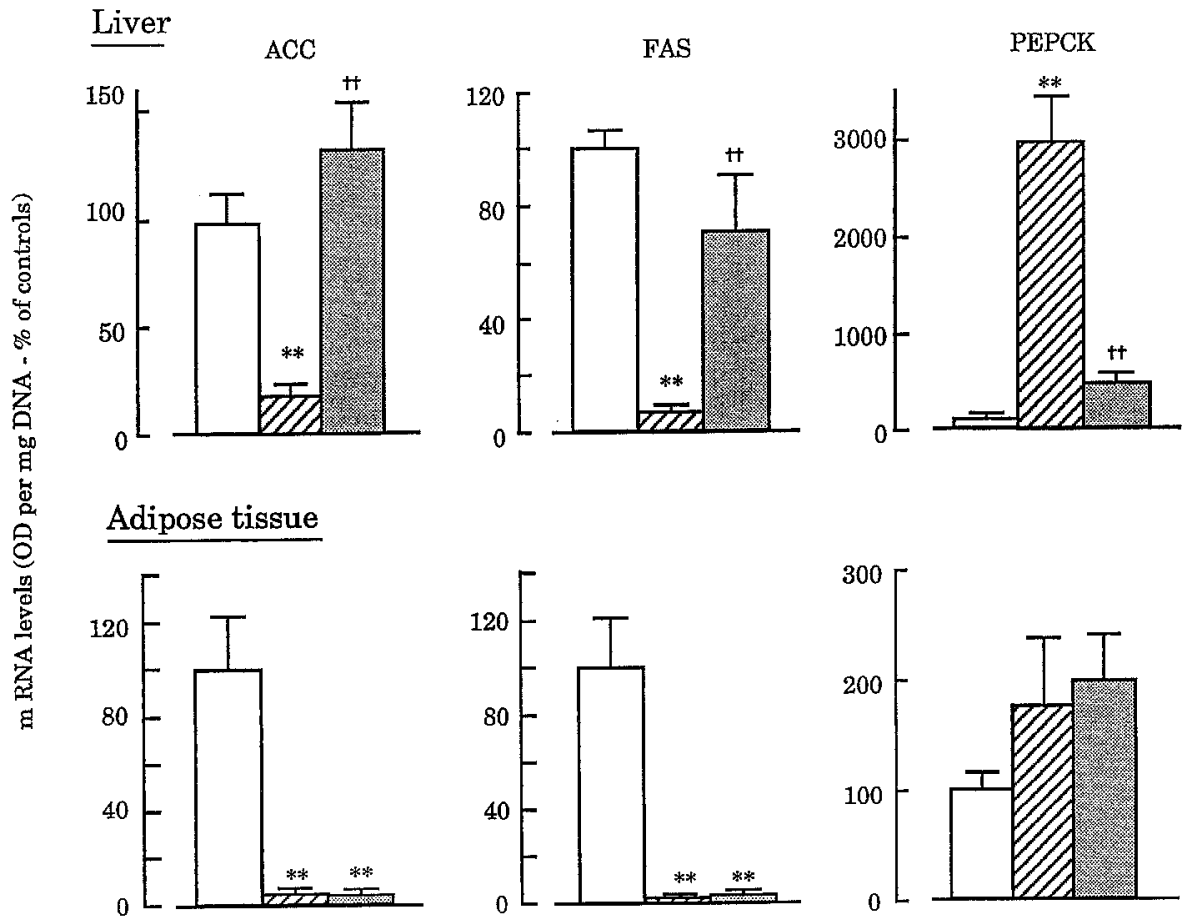

Fig. 2. Effects of vanadate treatment on acetyl-CoA carboxylase (ACC), fatty acid synthase (FAS) and phosphoenolpyruvate carboxykinase (PEPCK) mRNA levels in liver and white adipose tissue of diabetic rats. Values are means \pm SEM for 5-6 control (C), untreated diabetic (D) and vanadatetreated diabetic (V) rats. mRNA levels were quantified by scanning densitometry of autoradiographic signals obtained from Northern blots. The results were then calculated per mg DNA and expressed as percentages of values in control rats. Statistical significance of differences (analysis of variance followed by Newman-Keuls test):

** $p<0.01$ vs control rats; ${ }^{++} p<0.01$ vs untreated diabetic rats 
Table 3. Effects of vanadate treatment on acetyl-CoA carboxylase (ACC), fatty acid synthase (FAS) and phosphoenolpyruvate carboxykinase (PEPCK) activities in liver and white adipose tissue of diabetic rats

\begin{tabular}{|c|c|c|c|c|}
\hline & & Control & Diabetic & Diabetic + vanadate \\
\hline \multicolumn{5}{|l|}{ Liver } \\
\hline ACC & $\begin{array}{l}\text { (mU/mg protein) } \\
\text { (mU/mg DNA) }\end{array}$ & $\begin{array}{c}8.3 \pm 1.1 \\
102 \pm 13\end{array}$ & $\begin{array}{l}1.1 \pm 0.2^{b} \\
13 \pm 3^{b}\end{array}$ & $\begin{array}{l}3.7 \pm 0.7^{b, c} \\
46 \pm 7^{b, c}\end{array}$ \\
\hline \multirow{2}{*}{ FAS } & (mU/mg protein) & $18.6 \pm 1.7$ & $2.7 \pm 0.2^{b}$ & $11.1 \pm 0.7^{b, d}$ \\
\hline & (mU/mg DNA) & $305 \pm 24$ & $49 \pm 4^{b}$ & $200 \pm 19^{\mathrm{b}, \mathrm{d}}$ \\
\hline \multirow[t]{2}{*}{ PEPCK } & (mU/mg protein) & $8.0 \pm 0.8$ & $34.9 \pm 2.2^{\mathrm{b}}$ & $10.7 \pm 0.5^{\mathrm{d}}$ \\
\hline & $(\mathrm{mU} / \mathrm{mg} \mathrm{DNA})$ & $133 \pm 13$ & $637 \pm 25^{b}$ & $194 \pm 9^{\mathrm{a}, \mathrm{d}}$ \\
\hline \multicolumn{5}{|c|}{ White adipose tissue } \\
\hline \multirow{2}{*}{$\mathrm{ACC}$} & (mU/mg protein) & $8.0 \pm 1.0$ & $0.9 \pm 0.1^{b}$ & $0.9 \pm 0.1^{b}$ \\
\hline & $(\mathrm{mU} / \mathrm{mg} \mathrm{DNA})$ & $264 \pm 57$ & $19 \pm 4^{\mathrm{b}}$ & $23 \pm 9^{b}$ \\
\hline \multirow[t]{2}{*}{ FAS } & (mU/mg protein) & $51.5 \pm 9.5$ & $3.6 \pm 0.4^{b}$ & $4.3 \pm 0.4^{b}$ \\
\hline & (mU/mg DNA) & $2286 \pm 524$ & $106 \pm 33^{b}$ & $191 \pm 69^{b}$ \\
\hline \multirow[t]{2}{*}{ PEPCK } & (mU/mg protein) & $5.9 \pm 0.5$ & $9.3 \pm 0.7^{b}$ & $4.6 \pm 0.2^{\mathrm{d}}$ \\
\hline & $(\mathrm{mU} / \mathrm{mg}$ DNA) & $262 \pm 39$ & $257 \pm 69$ & $191 \pm 58$ \\
\hline
\end{tabular}

${ }^{\mathrm{a}} p<0.05,{ }^{\mathrm{b}} p<0.01$ vs control rats $;{ }^{\mathrm{c}} p<0.05,{ }^{\mathrm{d}} p<0.01$ vs untreated diabetic rats

RNA)) suggested an increase of this transcript in adipose tissue of both groups of diabetic rats (Fig. 1). However, scanning densitometry analyses of the autoradiograms revealed no significant differences between the three test groups. This remained true when data were expressed on a cellular basis (OD/ mg DNA) (Fig. 2). In agreement with the latter results, no significant difference was found among the three groups when PEPCK activity was expressed per mg DNA (Table 3). Interestingly, when expressed per mg protein, the activity of PEPCK was higher in diabetic rats, and this increase was corrected by vanadate treatment.

\section{Discussion}

We show that vanadate partially restores the activities of two key lipogenic enzymes in liver, but not in white adipose tissue, of insulin-deficient diabetic rats. We further demonstrate that this correction is explained by changes in corresponding mRNA levels.

As expected [26, 27], lipogenic enzyme activities were found to be depressed in both liver and adipose tissue of diabetic rats. The partial restoration of ACC and FAS activities in liver of vanadate-treated rats is in agreement with what has been recently reported for the activities of ATP-citrate lyase, malic enzyme and glucose 6-phosphate dehydrogenase in similarly-treated animals [9, 11]. The increase in ACC and FAS activities, observed in our study, is likely to reflect an increase in the amount of enzyme [28]. Indeed, FAS activity is known to closely parallel the enzyme content [26]. ACC activity is allosterically regulated, but the values obtained in the presence of $10 \mathrm{mmol} / \mathrm{l}$ citrate reflect the total amount of the enzyme [29].
Values are means \pm SEM for $5-6$ rats in each group. The anima ls were killed in the fed state after 20 days of treatment. White adipose tissue refers to epididymal fat pads

The restoration of lipogenic enzyme activities brought about by vanadate may completely be explained by an increase in corresponding mRNA levels. In agreement with previous reports [28, 30], we found that lipogenic enzyme gene expression was markedly reduced in liver and adipose tissue of diabetic rats. Vanadate treatment partially restored FAS mRNA and totally corrected ACC expression in diabetic liver. Several mechanisms may be involved.

First, the production of glycolytic metabolites. Evidence has been presented that glucose 6-phosphate could be the inducer of ACC and FAS gene expression in cultured cells [31]. This mechanism may explain how feeding fructose to insulinopenic diabetic rats led to a marked increase in lipogenic mRNA concentration and enzyme activity in liver $[32,33]$, but did not correct the low activity of FAS in adipose tissue [26]. In the liver of diabetic rats, fructose yields appreciable amounts of glycolytic intermediates [32] because the fructokinase activity is not markedly reduced despite the low activity of glucokinase (or hexokinase). Such a bypass of the first steps of glycolysis does not occur in adipose tissue which does not possess fructokinase $[26,28]$. Striking similarities exist between vanadate and fructose administration. Vanadate treatment of diabetic rats has been shown to induce glucokinase mRNA and activity, to restore fructose 2,6 bisphosphate concentrations and to stimulate overall glycolysis in the liver $[6,12,13,34]$. On the other hand, vanadate treatment of diabetic rats did not increase the low levels of GLUT 4 protein [35] or GLUT $4 \mathrm{mRNA}$ and hexokinase II mRNA (S. M. Brichard, unpublished data) in adipose tissue. This suggests that glycolytic intermediates, which are increased by vanadate in diabetic liver, may remain low in adipose tissue, 
which might explain the distinct effects of vanadate on lipogenic enzyme gene expression in the two tissues. Moreover, because glycolytic intermediates primarily stimulate the lipogenic enzyme transcription rate [32], it might also explain why post-transcriptional defects in hepatic ACC gene expression were not completely corrected by vanadate. Interestingly, the discrepancy between the total restoration of ACC mRNA and the partial correction of the activity of this enzyme in the liver of vanadate-treated rats has also been reported after fructose feeding [32].

Second, a restoration of triiodothyronine levels. $T_{3}$ has been shown to stimulate FAS gene in 3T3-L1 adipocytes [36] and the expression of several lipogenic enzymes in chick embryo or rat hepatocytes $[37,38]$. Diabetes may be associated with low thyroid hormone levels [39] and a frank hypothyroidism is usually present in the streptozotocin-diabetic rat [40]. $\mathrm{T}_{3}$ injection to diabetic rats strongly increased mRNA and activity of ACC and FAS in liver, this effect being more pronounced than in normal rats $[32,33]$. In agreement with previous reports $[41,42]$, we observed that vanadate treatment partially restored plasma $\mathrm{T}_{3}$ and $\mathrm{T}_{4}$ levels in diabetic rats. Such a correction may thus contribute to the changes in ACC and FAS gene expression.

Third, a decrease in NEFA levels. There exists an inverse relationship between hepatic lipogenesis and the concentration of plasma NEFA [43]. Since vanadate slightly decreased the elevated plasma NEFA levels of diabetic rats, this may also contribute to our findings.

Fourth, an alleviation of glucose toxicity. Vanadate restores the abnormal expression of genes coding for glycolytic and gluconeogenic enzymes in liver of diabetic rats $[12,13]$. Since this restoration is partly reproduced by phlorizin treatment, a drug which decreases glycaemia merely by inducing a renal leak of glucose, this improvement may result in part from attenuation of liver glucose toxicity [44]. Whether such a mechanism might also play a role in restoring the expression of lipogenic enzyme genes has not been directly addressed.

Fifth, an insulin-like action of vanadate on lipogenesis. Insulin treatment markedly increases the expression of several lipogenic enzyme genes in liver and adipose tissue of diabetic rats, mainly by stimulating their transcriptional rates $[28,30,32,33]$. Insulin and glucose have also been shown to be synergistically involved in ACC and FAS mRNA induction in cultured hepatocytes and adipocytes [31,38]. Likewise, vanadate stimulates fatty acid synthesis by isolated hepatocytes and adipocytes from normal rats [4548]. These observations are in agreement with our results in liver, but not with those in adipose tissue, where vanadate treatment had no effect on lipogenic enzyme re-induction in diabetic rats. It must be stres- sed, however, that except for studies in primary cultured hepatocytes [47], these in vitro insulin-like effects of vanadate were observed at concentrations of the element $(0.2-10 \mathrm{mmol} / \mathrm{l})[45,46,48]$ much higher than the levels $(20 \mu \mathrm{mol} / \mathrm{l})$ reached in the plasma of animals chronically treated with vanadium salts [3]. Aside from and independently of these insulin-like properties, vanadate also increases the insulin sensitivity of adipocytes $[49,50]$ and, at low concentrations $(50 \mu \mathrm{mol} / 1)$, potentiates the effects of the hormone on lipogenesis [49]. Differences in residual beta-cell function or diabetes severity might therefore account for different responses of lipid metabolism to vanadium treatment in adipose tissue of streptozotocin animals. This is supported by the recent ex vivo finding that lipolysis was normalized in adipose tissue from only a subgroup of vanadyl-treated diabetic rats, those whose insulin secretion was partly preserved and which had been made euglycaemic by the treatment [10]. One cannot exclude the possibility that the lack of effect of vanadate treatment on adipose tissue that we have observed is, at least to some extent, due to the incomplete correction of hyperglycaemia. On the other hand, there are other examples of distinct effects of insulin and vanadate on gene expression. Vanadate inhibits PEPCK gene transcription by acting on a regulatory element in the promoter, which is totally different from that involved in insulin action [51]. Regulatory regions of the FAS gene have not yet been identified. Two distinct promoters have been described for the ACC gene. An alternative usage of these promoters appears to be tissue-specific and sensitive to dietary or hormonal conditions that regulate lipogenesis (i.e. insulin, fat-free diet factor) $[52,53]$. One might speculate that vanadate mediates its effects on lipogenic genes, through promoter(s) distinct from those involved in insulin action, thereby producing tissue-selective responses. Eventually, even in liver, vanadate differs from insulin with regard to translation (or post-translation) of lipogenic enzymes. Insulin treatment totally corrects both ACC mRNA and activity, because the hormone affects both transcription and translation of lipogenic enzymes [28, 32]. This is obviously not the case for vanadate, which only partly corrected ACC activity in spite of a total restoration of ACC mRNA. It is not clear whether this discrepancy is due to the fact that vanadate is only a partial mimicker of the hormone or to the incomplete correction of high blood glucose levels achieved in our study.

In conclusion, vanadate treatment partially decreases hyperglycaemia and restores the activities of two key lipogenic enzymes (ACC and FAS) in liver, but not in white adipose tissue of diabetic rats. This restoration results from a reversal of impaired pretranslational regulatory mechanisms. Striking similarities between administration of vanadate and fruc- 
tose to diabetic rats suggest that glycolytic intermediates may play a major role in vanadate re-induction of liver lipogenic enzymes, although other mechanisms might also contribute.

Acknowledgements. We thank Drs. K. H. Kim (West Lafayette, Ind., USA), A. G. Goodridge (Iowa City, IA, USA) and R. W. Hanson (Cleveland Ohio, USA) for kindly providing us with the cDNA probes used in this study. We are grateful to Drs. J.-F Decaux, A. Leturque and D. Perderau for isolation of cDNA inserts, to Dr. D. Becker for scanning densitometry, to Dr. Ph. De Nayer for thyroid hormone measurements and to Mrs. A.-M Pottier for skilful assistance. This work was supported by Grants 1. 5. 078. 92 from the FNRS and 3. 4513.93 from the FRSM (Brussels). S.M.B. is Chercheur qualifie of the Fonds National de la Recherche Scientifique; she dedicates this work to Dr G. G. Brichard.

\section{References}

1. Mc Garry JD (1992) What if Minkowski had been ageusic? An alternative angle on diabetes. Science 258:766-770

2. Shechter Y (1990) Insulin mimetic effects of vanadate. Possible implications for future treatment of diabetes. Diabetes $39: 1-5$

3. Brichard SM, Lederer J, Henquin JC (1991) The insulinlike properties of vanadium: a curiosity or a perspective for the treatment of diabetes? Diabète Metab 17:435-440

4. Heyliger CE, Tahiliani AG, McNeill JH (1985) Effect of vanadate on elevated blood glucose and depressed cardiac performance of diabetic rats. Science 227:1474-1477

5. Meyerovitch J, Farfel Z, Sack J, Shechter Y (1987) Oral administration of vanadate normalizes blood glucose levels in streptozotocin-treated rats. J Biol Chem 262:6658-6662

6. Gil J, Miralpeix M, Carreras J, Bartrons R (1988) Insulinlike effects of vanadate on glucokinase activity and fructose 2,6-bisphosphate levels in the liver of diabetic rats. $J$ Biol Chem 263:1868-1871

7. Brichard SM, Okitolonda W, Henquin JC (1988) Long term improvement of glucose homeostasis by vanadate treatment in diabetic rats. Endocrinology 123:2048-2053

8. Blondel O, Bailbe D, Portha B (1989) In vivo insulin resistance in streptozotocin-diabetic rats - evidence for reversal following oral vanadate treatment. Diabetologia 32:185-190

9. Saxena AK, Srivastava P, Baquer NZ (1992) Effects of vanadate on glycolytic enzymes and malic enzyme in insulindependent and independent tissues of diabetic rats. Eur J Pharmacol 216:123-126

10. Cam MC, Pederson RA, Brownsey RW, McNeill JH (1993) Long-term effectiveness of oral vanadyl sulphate in streptozotocin-diabetic rats. Diabetologia 36:218-224

11. Pugazhenthi S, Angel JF, Khandelwal RL (1993) Effects of high sucrose diet on insulin-like effects of vanadate in diabetic rats. Mol Cell Biochem 122:77-84

12. Miralpeix M, Carballo E, Bartrons R, Crepin K, Hue L, Rousseau GG (1992) Oral administration of vanadate to diabetic rats restores liver 6-phosphofructo-2-kinase content and mRNA. Diabetologia 35:243-248

13. Brichard SM, Desbuquois B, Girard J (1993) Vanadate treatment of diabetic rats reverses the impaired expression of genes involved in hepatic glucose metabolism. Effects on glycolytic and gluconeogenic enzymes, and on glucose transporter GLUT 2. Mol Cell Endocrinol 91:91-97
14. Brichard SM, Pottier AM, Henquin JC (1989) Long term improvement of glucose homeostasis by vanadate in obese hyperinsulinemic fa/fa rats. Endocrinology 125:2510-2516

15. Chomczynski P, Sacchi N (1987) Single-step method of RNA isolation by acid guanidinium-thiocyanate-phenolchloroform extraction. Anal Biochem 162:156-159

16. Sambrook J, Fritsch EF, Maniatis T (1989) Extraction, purification and analysis of messenger RNA from eukaryotic cells. In: Ford N, Nolan C, Fergusson M (eds) Molecular cloning. A laboratory manual, Vol 1. Cold spring harbor laboratory press, New York, p 7.22

17. Bai DH, Pape ME, Lopez-Casillas F, Luo XC, Dixon JE, Kim KH (1986) Molecular cloning of cDNA for acetylCoA carboxylase. J Biol Chem 261:12395-12399

18. Nepokroeff CM, Adachi K, Yan C, Porter JW (1984) Cloning of DNA complementary to rat liver fatty acid synthetase mRNA. Eur J Biochem 146:441--445

19. Yoo-Warren H, Monahan JE, Short J et al. (1983) Isolation and characterization of the gene coding for cytosolic phosphoenolpyruvate carboxykinase (GTP) from the rat. Proc Natl Acad Sci USA 80:3656-3660

20. Linn TC (1981) Purification and crystallization of rat liver fatty acid synthetase. Arch Biochem Biophys 209:613-619

21. Maeda H, Ikeda I, Sugano M (1975) Behavior of the liver key enzymes in rats fed threonine imbalanced diet. Nutr Rep Int 12:61-66

22. Chang HC, Lane MD (1966) The enzymatic carboxylation of phosphoenolpyruvate. II. Purification and properties of liver mitochondrial phosphoenolpyruvate carboxykinase. J Biol Chem 241:2413-2420

23. Bradford M (1976) A rapid and sensitive method for the quantification of microgram quantities of protein utilizing the principle of protein-dye binding. Anal Biochem 72:248-254

24. Labarca C, Paigen K (1980) A simple, rapid, and sensitive DNA assay procedure. Anal Biochem 102:344-352

25. Sokal RR, Rohlf FJ (1969) Biometry. The principles and practice of statistics in biological research. Freeman, San Francisco, pp 1-776

26. Volpe JJ, Vagelos PR (1974) Regulation of mammalian fatty-acid synthetase.The roles of carbohydrate and insulin. Proc Natl Acad Sci USA 71:889-893

27. Volpe JJ, Marasa JC (1975) Hormonal regulation of fatty acid synthetase, acetyl-CoA carboxylase and fatty acid synthesis in mammalian adipose tissue and liver. Biochim Biophys Acta 380:454-472

28. Iritani N (1992) Nutritional and hormonal regulation of lipogenic-enzyme gene expression in rat liver. Eur J Biochem 205:433-442

29. Numa S, Nakanishi S, Hashimoto T, Iritani N, Okazaki T (1970) Role of acetyl-Coenzyme A carboxylase in the control of fatty acid synthesis. Vitam and Horm 28:213-243

30. Pape ME, Lopez-Casillas F, Kim KH (1988) Physiological regulation of acetyl-CoA carboxylase gene expression: effects of diet, diabetes, and lactation on acetyl-CoA carboxylase mRNA. Arch Biochem Biophys 267:104-109

31. Foufelle F, Gouhot B, Pégorier JP, Perdereau D, Girard J, Ferré P (1992) Glucose stimulation of lipogenic enzyme gene expression in cultured white adipose tissue. A role for glucose 6-phosphate. J Biol Chem 267:20543-20546

32. Katsurada A, Iritani N, Fukuda H, Matsumura Y, Nishimoto N, Noguchi T, Tanaka T (1990) Effects of nutrients and hormones on transcriptional and post-transcriptional regulation of acetyl-CoA carboxylase in rat liver. Eur J Biochem 190:435-441 
33. Katsurada A, Iritani N, Fukuda H, Matsumura Y, Nishimoto N, Noguchi T, Tanaka T (1990) Effects of nutrients and hormones on transcriptional and post-transcriptional regulation of fatty acid synthase in rat liver. Eur $\mathrm{J}$ Biochem 190:427-433

34. Valera A, Rodriguez-Gil JE, Bosch F (1993) Vanadate treatment restores the expression of genes for key enzymes in the glucose and ketone bodies metabolism in the liver of diabetic rats. J Clin Invest 92:4-11

35. Begum N, Draznin B (1992) Effect of streptozotocin-induced diabetes on GLUT-4 phosphorylation in rat adipocytes. J Clin Invest 90:1254-1262

36. Moustaid N, Sul HS (1991) Regulation of expression of the fatty acid synthase gene in 3T3-L1 cells by differentiation and triiodothyronine. J Biol Chem 266:18550-18554

37. Stapleton SR, Mitchell DA, Salati LM, Goodridge AG (1990) Triiodothyronine stimulates transcription of the fatty acid synthase gene in chick embryo hepatocytes in culture. J Biol Chem 265:18442-18446

38. Fukuda H, Katsurada A, Iritani N (1992) Nutritional and hormonal regulation of $\mathrm{mRNA}$ levels of lipogenic enzymes in primary cultures of rat hepatocytes. $\mathrm{J}$ Biochem $111: 25-30$

39. Saunders J, Hall SEH, Sonksen PH (1978) Thyroid hormones in insulin requiring diabetes before and after treatment. Diabetologia 15:29-32

40. Sundaresan PR, Sharma VK, Gingold SI, Banerjee SP (1984) Decreased $\beta$-adrenergic receptors in rat heart in streptozotocin-induced diabetes: role of thyroid hormones. Endocrinology 114:1358-1363

41. Ramanadham S, Mongold JJ, Brownsey RW, Cros GH, McNeill JH (1989) Oral vanadyl sulfate in treatment of diabetes mellitus in rats. Am J Physiol 257:H904-H911.

42. Oczelikay AT, Yildizoglu-Ari N, Ozuari A, Ozturk Y, Altan VM (1993) The effect of vanadate on alloxan-diabetic rat atria. Diabetes Res Clin Pr 19:189-194

43. Mayes PA (1993) Biosynthesis of fatty acids. In: Harper's Biochemistry. 23th edn. Appleton \& Lange, Prentice Hall, East Norwalk, pp 212-219
44. Brichard SM, Henquin JC, Girard J (1993) Phlorizin treatment of diabetic rats partially reverses the abnormal expression of genes involved in hepatic glucose metabolism. Diabetologia 36:292-298

45. Agius L, Vaartjes WJ (1982) The effects of orthovanadate on fatty acid synthesis in isolated rat hepatocytes. Biochem J 202:791-794

46. Guzman M, Castro J (1990) Simultaneous stimulation of fatty acid synthesis and oxidation in rat hepatocytes by vanadate. Arch Biochem Biophys 283:90-95

47. Jackson TK, Salhanick AI, Sparks JD, Sparks CE, Bolognino M, Amatruda JM (1988) Insulin-mimetic effects of vanadate in primary cultures of rat hepatocytes. Diabetes 37:1234-1240

48. Duckworth WC, Solomon SS, Liepnicks J, Hamel FG, Hand S, Peavy DE (1988) Insulin-like effects of vanadate in isolated rat adipocytes. Endocrinology 122:2285-2289

49. Fantus IG, Ahmad F, Deragon G (1990) Vanadate augments insulin binding and prolongs insulin action in rat adipocytes. Endocrinology 127:2716-2725

50. Eriksson JW, Lönnroth P, Smith U (1992) Vanadate increases cell surface insulin binding and improves insulin sensitivity in both normal and insulin-resistant rat adipocytes. Diabetologia 35:510-516

51. Bosch F, Hatzoglou M, Park EA, Hanson RW (1990) Vanadate inhibits expression of the gene for phosphoenolpyruvate carboxykinase (GTP) in rat hepatoma cells. J Biol Chem 265:13677-13682

52. Lopez-Casillas F, Kim KH (1989) Heterogeneity at the 5' end of rat Acetyl-Coenzyme A carboxylase mRNA. Lipogenic conditions enhance synthesis of a unique mRNA in liver. J Biol Chem 264:7176-7184

53. Lopez-Casillas F, Ponce-Castaneda MV, Kim KH (1992) Acetyl-Coenzyme A carboxylase mRNA metabolism in the rat liver. Metabolism 41:201-207 